\title{
EFEKTIVITAS KOAGULAN TERHADAP PENURUNAN PARAMETER LIMBAH CAIR INDUSTRI TAHU
}

\author{
Dewi Anggarwati ${ }^{1)}$
}

\begin{abstract}
Abstrak
Industri tahu di Kelurahan Gunung Sulah yang dijalankan masih berskala rumah tangga dan home industri. Hingga saat ini belum dilakukan pengolahan limbah cair, baik cara fisik, kimia, maupun biologis. Peneliti bertujuan mengetahui efektifitas koagulan Polyaluminium Chloride (PAC) dalam pengolahan limbah cair industri tahu. Eksperimen menggunakan rancangan Pretest-Posttest With Control Grup. Sampel penelitian diambil dari sentra industri tahu di Kelurahan Gunung Sulah, Kota bandar Lampung. Dosis PAC terdiri dari empat level $(75,150,225,300 \mathrm{mg} / \mathrm{l})$, demikian pula pada waktu pengadukan $(10,15,20,25$ menit). Parameter yang diamatai adalah COD dan TSS. Analisis statistik menggunakan uji Kruskal-Wallis. Pemeriksaan dilakukan pada Bulan Mei 2017 di Laboratorium Terpadu Politeknik Kesehatan Tanjungkarang. Hasil uji statistik menunjukkan dosis PAC yang efektif untuk menurunkan nilai COD dan TSS adalah $300 \mathrm{mg} / \mathrm{l}$. Waktu pengadukan lambat yang efektif untuk menurunkan nilai COD dan TSS adalah 25 menit. PAC dapat diterapkan dalam limbah industry dengan mengontrol $\mathrm{pH}$ agar tidak mencemari lingkungan.
\end{abstract}

Kata kunci : PAC, nilai COD, TSS

${ }^{1)}$ Alumni Prodi D4 Kesehatan Lingkungan Poltekkes Tanjungkarang

\section{PENDAHULUAN}

Kebutuhan tahu di Indonesia terus meningkat seiring dengan bertambahnya jumlah penduduk (Nirwana, 2016). Semakin tinggi produksi tahu tentunya akan menghasilkan limbah yang tinggi pula. Industri tahu menghasilkan limbah yang berpotensi mencemari lingkungan. Diperkirakan, setiap pengolahan $1 \mathrm{~kg}$ kacang kedelai menjadi tahu akan menghasilkan limbah cair sebanyak 15-20 liter (Sadzaii, 2010). Air limbah industri secara umum memiliki tiga sifat yaitu sifat fisik berupa warna yang keruh, temperatur (suhu) tinggi, zat tersuspensi meningkat dan berbau. Sifat kimia ditentukan oleh biochemical oxygen demand (BOD), chemical oxygen demand (COD), total suspended solid (TSS) dan logamlogam berat (misal besi dan magnesium). Sifat biologis berupa kandungan bakteri-bakteri patogen di dalam air limbah (Haryaningsih, 2015). Karakteristik limbah cair tahu antara lain temperaturnya melebihi temperatur normal badan air penerima $\left(60-80^{\circ} \mathrm{C}\right)$, warna limbah putih kekuningan dan keruh, COD sebesar 1534 $\mathrm{mg} / \mathrm{l}$, BOD sebesar $950 \mathrm{mg} / \mathrm{l}$, dan TSS sebesar $309 \mathrm{mg} / \mathrm{l}$. Kandungan limbah cair berupa kulit kedelai, selaput lendir, protein, lemak dan karbohidrat (Haryaningsih, 2015).
Salah satu teknologi pengolahan air limbah yaitu pengolahan secara kimia dengan koagulasi. Koagulasi adalah proses pencampuran koagulan (bahan kimia) atau pengendap ke dalam air baku dengan kecepatan perputaran yang tinggi dalam waktu yang singkat. Polyalumunium Chloride (PAC) merupakan salah satu pengganti alum padat yang efektif karena menghasilkan koagulasi air dengan kekeruhan yang berbeda dengan cepat, menggenerasi lumpur lebih sedikit, dan juga meninggalkan lebih sedikit residu alumunium pada air yang diolah (Malhotra, 1994 dalam Kristijarti dkk, 2013). Menurut Echanpin (2005) dalam Said (2009), PAC memiliki kelebihan dengan tingkat adsorpsi yang kuat, mempunyai kekuatan lekat, tingkat pembentukan flok-flok tinggi meski dengan dosis kecil, memiliki tingkat sedimentasi yang cepat, cakupan penggunaannya luas, dan konsumsinya cukup pada konsentrasi rendah.

Hasil penelitian yang dilakukan oleh A. Prima Kristijarti, dkk (2013), menggunakan metode koagulasi-flokulasi dalam pengolahan air limbah pabrik jamu dengan PAC mendapatkan hasil yang lebih baik dibandingkan dengan $\mathrm{FeSO}_{4}$. Dosis $\mathrm{PAC}$ yang menyebabkan penyisihan paling tinggi adalah 
$0,163 \mathrm{~g} / \mathrm{l}$, atau mencapai $99,24 \%$. Hasil penelitian Bastian (2016) mendapatkan rerata nilai COD pada limbah tahu di Kelurahan Gunung Sulah adalah $4.000 \mathrm{mg} / \mathrm{L}$ dan TSS sebesar $1.150 \mathrm{mg} / \mathrm{l}$, jauh melebihi baku mutu air limbah menurut Peraturan Mentri Lingkungan Hidup N0.5 tahun $2014(\mathrm{COD}=150 \mathrm{mg} / \mathrm{l}$, dan TSS $=200 \mathrm{mg} / \mathrm{L}$ ).

Industri tahu di Kelurahan Gunung Sulah dijalankan masih berskala rumah tangga (home industry). Hingga saat ini belum dilakukan pengolahan limbah, sehingga limbah cair hanya dialirkan ke selokan dan sungai. Kondisi ini menimbulkan keluhan dari masyarakat akibat bau yang ditimbulkan, mengingat Kelurahan Gunung Sulah merupakan kawasan padat penghuni.

Penelitian bertujuan mengetahui efektifitas PAC dalam pengolahan limbah cair industri tahu. Variabel yang diuji adalah dosis (empat level) dan waktu pengadukan (empat level). Parameter limbah yang dinilai adalah COD dan TSS.

\section{METODE}

Penelitian ini merupakan penelitian eksperimen dengan rancangan Pretest-Posttest With Control Grup untuk menilai kemampuan PAC dalam menurunkan nilai COD dan TSS pada limbah cair tahu. Penelitian dilaksanakan dalam skala laboratorium, dan dilaksanakan di Laboratorium Terpadu Politeknik Kesehatan Tanjungkarang. Sampel diambil dari sentra industri tahu di Kelurahan Gunung Sulah, Kota Bandar Lampung. Penelitian ini dilakukan pada bulan Mei 2017.

Variasi dosis sebanyak empat level $(75,150$, $225,300 \mathrm{mg} / \mathrm{l})$, demikian pula pada waktu pengadukan $(10,15,20,25$ menit). Percobaan dilakukan sebanyak 16 perlakuan dengan 2 kali pengulangan. Uji statistik menggunakan uji Kruskal-Wallis, karena data tidak terdistribusi normal.

\section{HASIL}

\section{Nilai COD dan TSS sebelum dan sesudah perlakuan}

Proses koagulasi dimulai dengan pengadukan cepat selama 1 menit dengan kecepatan $120 \mathrm{rpm}$, dilanjutkan pengadukan lambat dengan kecepatan 40-50 rpm dengan waktu yang ditentukan dalam penelitian ini yaitu 10 menit, 15 menit, 20 menit dan 25 menit. Proses pengadukan cepat bertujuan unuk mendispersikan koagulan dengan air limbah agar dapat bercampur dengan sempurna. Sedangkan pengadukan lambat bertujuan untuk membantu pembentukan flok-flok dengan ukuran lebih besar. Hingga saat pengendapan dapat mengendap secara sempurna.

Hasil pemeriksaan fisik sampel sesudah penambahan PAC menunjukkan perubahan warna menjadi kuning, dan semakin pekat jika dosis yang ditambahkan semakin banyak. Nilai $\mathrm{pH}$ limbah cair tahu sebelum perlakuan sebesar 5,00 , dan setelah perlakuan menjadi 4,35. Pengukuran suhu selama percobaan tidak menunjukkan perubahan, yaitu sebesar $28^{\circ} \mathrm{C}$.

Pada waktu pengadukan 10 menit pembentukan flok relatif kecil, dengan penambahan waktu pengadukan terlihat ukuran flok yang semakin besar setiap 5 menit penambahan waktu pengadukan lambat hingga menit ke 25 bentuk flok semakin besar. Penambahan dosis pada dosis $75 \mathrm{mg} / \mathrm{l}$, hasil endapan yang dihasilkan lebih sedikit dibandingkan dengan dosis $150,225,300 \mathrm{mg} / \mathrm{l}$, yang artinya semakin banyak penambahan dosis maka endapan/lumpur yang dihasilkan semakin banyak.

Pada Tabel 1 terlihat bahwa nilai COD sebelum penambahan PAC pada sebesar 8600 ppm. Setelah perlakuan, persentase penurunan terendah pada dosis PAC $75 \mathrm{mg} / 1$, sebesar $42,63 \%$ (4933,75 ppm). Sedangkan persentase tertinggi pada dosis $300 \mathrm{mg} / \mathrm{l}$, sebesar $62,88 \%$ $(3192,5 \mathrm{ppm})$. Pada kelompok kontrol, nilai COD turun menjadi $8198,25(4,67 \%)$.

Nilai TSS sebelum penambahan PAC sebesar $4875 \mathrm{ppm}$. Setelah perlakuan, persentase penurunan terendah sebesar $56,03 \%$ $(2143,75 \mathrm{ppm})$ yaitu pada penambahan dosis 75 $\mathrm{mg} / \mathrm{l}$. Persentase penurunan tertinggi $(72,56 \%)$ pada penggunaan dosis $300 \mathrm{mg} / \mathrm{l}$, menjadi $1337,50 \mathrm{ppm}$. Pada kelompok kontrol, COD turun menjadi $4661,00(4,39 \%)$. 
Tabel 1. Nilai COD dan TSS sebelum dan sesudah perlakuan

\begin{tabular}{llllllll}
\hline $\begin{array}{l}\text { Penambahan } \\
\text { Dosis PAC }\end{array}$ & $\begin{array}{l}\text { Sebelum } \\
\text { perlakuan }\end{array}$ & $\begin{array}{l}\text { Sesudah } \\
10 \text { ment }\end{array}$ & 15 menit & 20 menit & 25 menit & Rata-rata & $\begin{array}{l}\text { Penurunan } \\
(\%)\end{array}$ \\
\hline Nilai COD & & & & & & & \\
0 & 8600,00 & 8163,75 & 8267,50 & 8183,75 & 8178,00 & 8198,25 & 4,67 \\
75 & 8600,00 & 8000,00 & 6015,00 & 3640,00 & 2080,00 & 4933,75 & 42,63 \\
150 & 8600,00 & 7680,00 & 5470,00 & 3280,00 & 1260,00 & 4422,50 & 48,58 \\
225 & 8600,00 & 6700,00 & 4960,00 & 2580,00 & 680,00 & 3730,00 & 56,63 \\
300 & 8600,00 & 6360,00 & 4160,00 & 2120,00 & 130,00 & 3192,50 & 62,88 \\
Nilai TSS & & & & & & & 4,39 \\
0 & 4875,00 & 4780,00 & 4719,00 & 4701,25 & 4443,75 & 4661,00 & 4,39 \\
75 & 4875,00 & 4245,00 & 2090,00 & 1350,00 & 890,00 & 2143,75 & 56,03 \\
150 & 4875,00 & 3010,00 & 1890,00 & 1250,00 & 650,00 & 1700,00 & 65,13 \\
225 & 4875,00 & 2700,00 & 1810,00 & 1170,00 & 370,00 & 1512,50 & 68,97 \\
300 & 4875,00 & 2470,00 & 1680,00 & 960,00 & 240,00 & 1337,50 & 72,56 \\
\hline
\end{tabular}

\section{Pengaruh dosis terhadap COD dan TSS}

Dari Tabel 2 terlihat bahwa hasil analisis Kruskal-Wallis mendapatkan nilai p-value lebih kecil dari 0,05 , menunjukkan perbedaan nilai COD yang signifikan berdasarkan dosis PAC yang digunakan $(0 \mathrm{mg} / 1,75 \mathrm{mg} / \mathrm{l}, 150 \mathrm{mg} / \mathrm{l}, 225$ $\mathrm{mg} / 1$ dan $300 \mathrm{mg} / \mathrm{l})$. Hasil uji Mann-whitney (Tabel 3) menujukkan perbedaan nilai COD antara kontrol dengan kelompok perlakuan. Sedangkan antar kelompok perlakuan, tidak menunjukkan perbedaan nilai COD yang nyata.
Pada variabel dosis PAC terhadap nilai TSS, diperoleh nilai p-value lebih kecil dari 0,05 , menunjukkan perbedaan nilai TSS yang signifikan berdasarkan dosis PAC yang digunakan $(0 \mathrm{mg} / 1,75 \mathrm{mg} / 1,150 \mathrm{mg} / \mathrm{l}, 225 \mathrm{mg} / \mathrm{l}$ dan $300 \mathrm{mg} / \mathrm{l}$ ). Hasil uji Mann-whitney (Tabel 3) menyatakan perbedaan nilai TSS antara kontrol dan kelompok perlakuan (p-value< $0,05)$, sedangkan antar kelompok perlakuan tidak terdapat perbedaan nilai TSS.

Tabel 2. Analisis Kruskal-Wallis terhadap dosis

\begin{tabular}{lllll}
\hline Parameter & Chi-Square & DF & p-valuc \\
\hline Dosis & COD & 47,089 & 4 & 0,0001 \\
& TSS & 44,757 & 4 & 0,0001 \\
\hline
\end{tabular}

Tabel 3. Hasil analisis Mann-whitney

\begin{tabular}{llllll|lllllll}
\hline COD & & & & & TSS & & & & & \\
Dosis & 0 & 75 & 150 & 225 & 300 & Dosis & 0 & 75 & 150 & 225 & 300 \\
\hline 0 & - & $<0,05$ & $<0,05$ & $<0,05$ & $>0,05$ & 0 & - & $<0,05$ & $<0,05$ & $<0,05$ & $>0,05$ \\
75 & $<0,05$ & - & $>0,05$ & $>0,05$ & $>0,05$ & 75 & $<0,05$ & - & $>0,05$ & $>0,05$ & $>0,05$ \\
150 & $<0,05$ & $>0,05$ & - & $>0,05$ & $>0,05$ & 150 & $<0,05$ & $>0,05$ & - & $>0,05$ & $>0,05$ \\
225 & $<0,05$ & $>0,05$ & $>0,05$ & - & $>0,05$ & 225 & $<0,05$ & $>0,05$ & $>0,05$ & - \\
300 & $<0,05$ & $>0,05$ & $>0,05$ & $>0,05$ & - & 300 & $<0,05$ & $>0,05$ & $>0,05$ & $>0,05$ & - \\
\hline
\end{tabular}

\section{Pengaruh waktu terhadap COD dan TSS}

Pada variabel waktu pengadukan lambat terhadap nilai COD (Tabel 4) diperoleh nilai pvalue $<0,05$, menunjukkan perbedaan signifikan nilai COD limbah cair tahu berdasarkan lama waktu pengadukan lambat (10 menit, 15 menit, 20 menit dan 25 menit). Hasil uji Mann-whitney menunjukkan perbedaan signifikan nilai COD pada semua waktu pengadukan (Tabel 5).

Pada Tabel 4 juga terlihat bahwa TSS berbeda berdasarkan lama waktu pengadukan (p-value $<0,05$ ). Hasil uji Bonferoni (Tabel 5) juga menunjukkan perbedaan signifikan nilai COD pada semua waktu pengadukan. 
Tabel 4. Analisis Kruskal-Wallis terhadap waktu

\begin{tabular}{lllll}
\hline Parameter & Chi-Square & DF & p-value \\
\hline Waktu & COD & 107,043 & 3 & 0,0001 \\
& TSS & 53,538 & 3 & 0,0001 \\
\hline
\end{tabular}

Tabel 5. Hasil analisis Mann-whitney

\begin{tabular}{|c|c|c|c|c|c|c|c|c|c|}
\hline $\begin{array}{l}\text { COD } \\
\text { Waktu }\end{array}$ & 10 menil & 15 menit & 20 menit & 25 menil & $\begin{array}{l}\text { TSS } \\
\text { Waktu }\end{array}$ & 10 menii & 15 menit & 20 menil & 25 menit \\
\hline 10 menit & - & $<0,05$ & $<0,05$ & $<0,05$ & 10 menit & - & $<0,05$ & $<0,05$ & $<0,05$. \\
\hline 15 menit & $<0,05$ & - & $<0,05$ & $<0,05$ & 15 menit & $<0,05$ & - & $<0,05$ & $<0,05$ \\
\hline 20 menit & $<0,05$ & $<0,05$ & - & $<0,05$ & 20 menit & $<0,05$ & $<0,05$ & - & $<0,05$ \\
\hline 25 menit & $<0,05$ & $<0,05$ & $<0,05$ & - & 25 menit & $<0,05$ & $<0,05$ & $<0,05$ & - \\
\hline
\end{tabular}

\section{PEMBAHASAN}

\section{Nilai COD dan TSS sebelum dan sesudah perlakuan}

Hasil pemeriksaan awal COD dan TSS didapatkan nilai sebesar 8600 ppm dan 4875 ppm, jauh melebihi baku mutu air limbah pada kegiatan pengolahan kedelai (Peraturan Menteri Lingkungan Hidup No 5 tahun 2014), yaitu sebesar 300 ppm untuk COD dan 150 ppm untuk dan TSS. Limbah cair industri tahu merupakan salah satu limbah cair yang mengandung bahan organik yang tinggi. Limbah cair mengandung padatan tersuspensi atau terlarut yang akan mengalami perubahan fisika, kimia, dan hayati sehingga menimbulkan gangguan kesehatan (Kaswinarni, 2007).

Meningkatnya nilai COD limbah industri tahu karena limbah industri tahu termasuk limbah biodegradable, yaitu limbah yang dapat diuraikan oleh mikroorganisme yang memerlukan oksigen dalam jumlah tertentu. Meningkatnya angka COD akan diikuti dengan meningkatnya kebutuhan oksigen untuk penguraian bahan organik. Pada saat oksigen yang dibutuhkan tidak mencukupi untuk mengurai bahan-bahan organik, sementara limbah industri tahu terus menerus dibuang ke sungai maka akan menimbulkan pencemaran yang berpengaruh terhadap kualitas air sungai.

Tabel 2 nilai COD kelompok kontrol sebesar 8198,25 ppm dengan persentase penurunan $4,67 \%$. Sedangkan penambahan dosis dengan hasil persentase terendah $42,63 \%$ yaitu pada dosis $75 \mathrm{mg} / \mathrm{l}$ dengan rata-rata nilai COD sebesar 4933,75 ppm. Persentase penurunan tertinggi $(62,88 \%)$ pada dosis $300 \mathrm{mg} / 1$, dengan rata-rata nilai COD sebesar 3192,5 ppm. Tingginya nilai COD akan menyebabkan berkurangnya oksigen terlarut dalam air. Pada nilai COD yang tinggi, dibutuhkan oksigen dalam jumlah yang besar untuk mengurai zatzat organik pada air. Berkurangnya oksigen terlarut akan menyebabkan kematian pada biota air sehingga merusak ekosistem yang terdapat di dalamnya (Nurhasanah, 2009).

Nilai TSS kelompok kontrol sebesar 4661 ppm dengan persentase penurunan 4,39\%. Sedangkan pada penambahan dosis dengan hasil persentase terendah $(56,03 \%)$ pada dosis $75 \mathrm{mg} / \mathrm{l}$ dan tertinggi $(72,56 \%)$ pada dosis 300 mg/l. TSS mempunyai efek yang kurang baik terhadap kualitas air karena menyebabkan kekeruhan dan mengurangi cahaya yang dapat masuk ke dalam air. Oleh karenanya, manfaat air dapat berkurang, dan organisme yang butuh cahaya akan mati. Kematian organisme ini akan mengganggu ekosistem akuatik. Apabila jumlah materi tersuspensi ini akan mengendap, maka pembentukan lumpur dapat sangat mengganggu aliran dalam saluran, pendangkalan cepat terjadi, sehingga diperlukan pengerukan lumpur yang lebih sering (Soemirat,2004). Pada penelitian ini terlihat bahwa semakin tinggi dosis koagulan PAC yang diberikan semakin besar penurunan nilai COD dan TSS limbah cair tahu.

\section{Pengaruh Dosis}

Kemampuan PAC menurunkan nilai COD terlihat pada Tabel 2 dan Tabel 3. Hasil uji Mann-whitney menunjukkan perbedaan nilai COD yang signifikan antara kontrol dan kelompok perlakuan ( $\mathrm{p}$-value $<0,05$ ). Hasil penelitian sesuai dengan hasil penelitian Retno Dwi Hariyanti (2015) yang menyimpulkan bahwa penambahan PAC dapat menurunkan nilai COD pada air limbah.

Koagulasi dengan PAC dapat menurunkan nilai COD karena sebagian besar partikulat yang berada dalam air limbah telah terikat dan mengendap bersama dengan koagulan sehingga menurunkan jumlah partikel yang berada dalam air limbah. Penurunan COD disebabkan flok yang terbentuk oleh ion senyawa organik 
berikatan dengan senyawa ion koagulan yang bersifat positif. Molekul-molekul pada limbah terbentuk menjadi flok, partikel koloid pada limbah bersifat mengikat partikel atau senyawa lain yang ada pada limbah. Dengan menurunnya jumlah partikel, maka oksigen yang diperlukan untuk mengoksidasi senyawa organik juga menurun, sehingga nilai COD setelah koagulasi menjadi rendah.

Pada Tabel 4 menunjukkan perbedaan nilai TSS limbah cair tahu berdasarkan dosis PAC yang digunakan $(0 \mathrm{mg} / 1,75 \mathrm{mg} / \mathrm{l}, 150 \mathrm{mg} / 1,225$ $\mathrm{mg} / \mathrm{l}, \quad 300 \mathrm{mg} / \mathrm{l})$. Tabel 5 memperlihatkan perbedaan TSS antara kontrol dan kelompok perlakuan ( $p$-value $<0,05)$. Hasil penelitian sesuai dengan Kartika (2015) yang menyimpulkan bahwa penambahan koagulan PAC berpengaruh signifikan terhadap penurunan TSS pada air limbah.

Padatan tersuspensi dan terlarut akan mengalami perubahan fisika, kimia dan hayati sehingga menghasilkan zat toksik yang merugikan manusia. Jika dibiarkan di lingkungan tanpa pengolahan, air limbah akan berubah warna menjadi coklat dan berbau busuk. Perubahan warna ini diakibatkan kadar oksigen dalam air menjadi nol. Apabila berada di sekitar sumber air, kemungkinan akan merembes sehingga mencemari sumber air sehingga tidak dapat dimanfaatkan (Nurhasan; Pramudyanto, 1991)

Menurut Sugiharto (2008), pH yang baik untuk air limbah adalah netral. Jika $\mathrm{pH}$ air limbah tidak netral, dapat mengganggu proses penjernihan. Pada penelitian ini, hasil pengukuran $\mathrm{pH}$ sebelum perlakuan adalah 5,00 , dan sesudah perlakuan turun menjadi 4,35. Penurunan $\mathrm{pH}$ disebabkan adanya penambahan kation dari koagulan (PAC) untuk menetralisasi muatan pada limbah. Proses koagulasi dapat terjadi jika muatan partikel mempunyai gaya tarik yang kuat terhadap partikel koloid. Agar penurunan nilai TSS optimal, dilakukan pengendalian nilai $\mathrm{pH}$ tetap pada kondisi normal. Salah satu cara untuk menetralkan $\mathrm{pH}$ pada air limbah adalah menggunakan kapur tohor $(\mathrm{CaO})$. Kapur tohor dapat menetralkan $\mathrm{pH}$ pada air limbah yang bersifat asam karena akan bereaksi menghasilkan $\mathrm{Ca}(\mathrm{OH})_{2}$ (kalsium hidroksida) yang discbut slaked lime (kapur mati) dan menghasilkan gugus hidroksil yaitu $\mathrm{Ca}(\mathrm{OH})_{2}$ yang bersifat basa.

\section{Pengaruh waktu pengadukan}

Tabel 4 menunjukkan perbedaan nilai COD berdasarkan lama waktu pengadukan (pvalue<0,05). Hasil uji Mann-whitney (Tabel 5) menunjukkan perbedaan nilai $\mathrm{COD}$ yang signifikan antara kelompok perlakuan ( $p$-value< $0,05)$. Hasil penelitian juga mendapatkan bahwa waktu pengadukan optimal adalah selama 25 menit, menunjukkan penurunan COD. hingga $130 \mathrm{ppm}$. Pada waktu pengadukan 25 menit, flok-flok organik pecah dengan hebatnya, sehingga kemungkinan hampir seluruh flok organik yang terbentuk terurai kembali menjadi partikel organik tunggal, sehingga dihasilkan air umpan setelah koagulasi yang paling keruh dibandingkan dengan yang dihasilkan dengan waktu-waktu pengadukan lainnya, yang menandakan terkonsentrasinya partikel organik dalam jumiah besar. Pengadukan lambat merupakan bagian dari proses flokulasi setelah penambahan bahan kimia. Flokulasi adalah proses pengendapan pencemar dalam limbah cair dengan penambahan bahan koagulan utama dan koagulan pendukung sehingga terjadi gumpalan sebelum mencapai dasar tangki pengendap. Flokulasi dikenal juga sebagai pencampuran (mixing). Namun kecepatan pencampuran sangat lambat dan tangki flokulasi dilengkapi dengan pengaduk bentuk pedal, dan buffel atau sirip didinding tangki flokulasi (Suharto, 2011: 342).

Dari tabel 2 diperoleh nilai P-value $0,00<$ 0,05 , dapat diartikan bahwa terdapat perbedaan nilai TSS limbah cair tahu pada waktu pengadukan lambat (10 menit, 15 menit, 20 menit dan 25 menit). Nilai TSS maksimum Pada waktu pengadukan lambat 10 menit sebesar $4720 \mathrm{ppm}$. Nilai TSS minimum pada waktu pengadukan lambat 25 menit sebesar 240 ppm..

Keefektivan waktu pengadukan lambat dalam menurunkan nilai TSS limbah tahu tabel 4.5 dengan uji bonferoni dapat dilihat bahwa antar kelompok mempunyai perbedaan signifikan antar nilai TSS dengan $(P)<0,05$ terlihat bahwa pada waktu pengadukan 25 menit terjadi penurunan optimal mencapai 240 ppm. Penambahan waktu pengadukan pelan akan menaikkan efektifitas koagulasi hingga dicapai waktu pengadukan pclan yang optimum, dimana pertumbuhan flok sudah mencapai titik maksimalnya.

Pengadukan lambat akan memperpendek jarak antar partikel sehingga gaya tarik menarik antar partikel menjadi lebih besar dan dominan 
dibandingkan gaya tolakannya yang menghasilkan kontak dan tumbukan antar partikel yang lebih banyak dan lebih sering. Kontak inilah yang menggumpalkan partikel padat terlarut terkoagulasi berukuran mikro menjadi partikel flok yang lebih besar. Flokflok ini akan beragregasi. Ketika pertumbuhan flok sudah cukup maksimal (masa, ukuran) selanjutnya akan mengendap kedasar reservoir, sehingga terbentuk dua lapisan. Lapisan air jernih pada bagian atas reservoir dan lapisan endapan flok yang menyerupai lumpur pada dasar reservoir (Karamah, Lubis ; 2004).

PAC merupakan koagulan yang murah dan mudah didapatkan, namun apabila digunakan dalam jangka panjang perlu diperhatikan lagi jumlah kebutuhannya. Perhitungan kebutuhan bahan dan biaya koagulan PAC dengan dosis optimum $300 \mathrm{mg} / \mathrm{l}$ dan waktu pengadukan lambat 25 menit pada pengolahan air limbah tahu adalah sebagai berikut:

Estimasi air limbah perhari :

- $1 \mathrm{~kg}$ kedelai menjadi tahu menghasilkan air limbah 15-20 liter.

- Volume air Limbah setiap hari :

$75 \mathrm{~kg}$ kedelai

- Kebutuhan koagulan perhari

- Biaya bahan koagulan per hari

Biaya PAC

$$
\begin{aligned}
& =75 \times 20 \text { liter } \\
& =1500 \mathrm{liter} / \mathrm{hari} \\
& =300 \mathrm{mg} / 1 \times 1500 \text { liter } \\
& =450 \mathrm{gr} / \text { hari }
\end{aligned}
$$

Biaya kebutuhan PAC perhari

$$
=\mathrm{Rp} \cdot 20.000,-/ \mathrm{kg}
$$$$
=\frac{450 \mathrm{gr} / \mathrm{hari} \times \mathrm{Rp} \cdot 20.000,-/ \mathrm{kg}}{1000 \mathrm{gr}}
$$

$$
=\text { Rp. } 9000,-/ \text { hari }
$$

Cara mengaplikasikan dosis optimum ke dalam pengolahan air limbah tahu sebagai berikut :

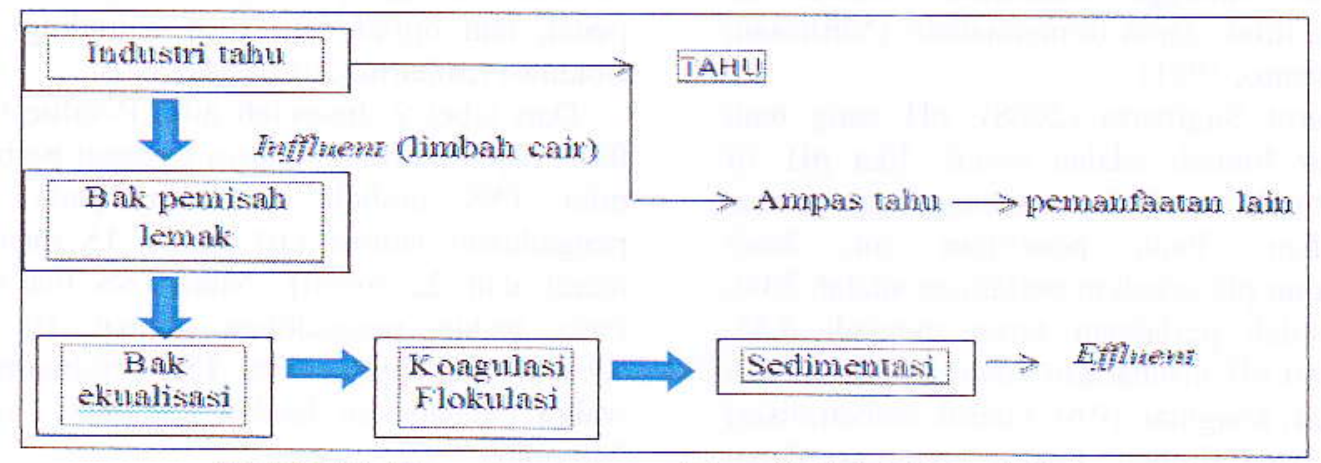

Gambar 1. Bagan proses pengolahan limbah tahu sederhana

a. Bak pemisah lemak/minyak

Bak pemisah lemak/skimmer direncanakana direncanakan untuk mengurangi beban organik berupa lemak. Minyak atau lemak yang telah mengapung keatas permukaan akan di scrup/dikikis menggunakan scraper dengan jangka waktu 1-2 minggu tergantung dari jumlah minyak/lemak yang dihasilkan.

b. Bak equalisasi

Setelah dari bak pemisah minyak dialirkan menuju ke bak ekualisasi yang berfungsi sebagai penampung limbah dan kontrol aliran limbah. c. Koagulasi

Limbah cair yang telah diolah di bak aerobik kemudian masuk ke proses koagulasi, disini proses koagulasi dengan penambahan bahan koagulan PAC (Polyalumunium Chloride) dengan dosis yang telah ditentukan sebelumnya, diaduk menggunakan Rapid Mixing dengan kecepatan $120 \mathrm{rpm}$ selama satu menit.

d. Flokulasi

Air limbah tahu kemudian masuk keproses flokulasi dengan waktu pengadukan lambat yang telah ditentukan sebelumnya, 
pengadukan menggunaka slow mixing dengan kecepatan pengadukan $40 \mathrm{rpm}$.

e. Sedimentasi

Pengolahan selanjutnya setelah proses koagulasi dan flokulasi air limbah cair tahu kemudian dialirkan menuju ke bak sedimentasi. Sedimentasi adlah pemisahan partikel dari air dengan memanfaatkan gaya gravitasi. Proses ini bertujuan untuk memperoleh proses penanganan lumpur. Pada bak sedimentasi berbentuk silinder dengan dasar berbentuk kerucut runcing agar endapan mudah terkumpul yang selanjutnya akan dibuang ke output.

Tabel 3. Perkiraan Kualitas Effluent dari proses Pengolahan

\begin{tabular}{lll}
\hline \multirow{2}{*}{ Section } & Parameter & \\
\cline { 2 - 3 } & COD $(\mathrm{mg} / \mathrm{l})$ & TSS $(\mathrm{mg} / \mathrm{l})$ \\
\hline Inffluent & 8600 & 4875 \\
Skimmer & $0 \%$ & $5 \%$ \\
& 8600 & 4631,25 \\
Bak ekualisasi & $0 \%$ & $15 \%$ \\
Koagulasi & 8600 & 3936,55 \\
Flokulasi & $98,4 \%$ & $95 \%$ \\
Sedimentasi & 130 & 196,85 \\
Effluent & $70 \%$ & $70 \%$ \\
\hline
\end{tabular}

Biaya yang diperlukan untuk pembuatan unit pengolahan limbah tahu berkisar Rp. 1.321 .000 ,- terdiri dari pembuatan bak pemisah lemak (Rp. 166.000,-), bak equalisi (Rp. $385.000,-)$, bak koagulasi flokulasi (Rp. $385.000,-$ ) dan bak sedimentasi (Rp. $385.000,-$ ).

\section{KESIMPULAN}

Dosis PAC yang efektif terhadap nilai COD dan TSS limbah cair tahu yaitu $300 \mathrm{mg} / \mathrm{l}$ dengan nilai COD $130 \mathrm{ppm}$ dan TSS $240 \mathrm{ppm}$. Waktu pengadukan lambat yang efektif terhadap nilai COD dan TSS limbah cair tahu selama 25 menit .

\section{DAFTAR PUSTAKA}

Azamia M. (2012). Pengolahan Limbah Cair Laboratorium Kimia Dalam Penurunan Nilai Organik Serta Logam Berat Fe, Mn, $\mathrm{Cr}$ Dengan Metode Koagulasi Dan Adsorbsi. Skripsi. Jakarta: UI

Fuadi A, Munawar, Mulyani. (2013). Penentuan Karakteristik Air Waduk Dengan Metode Koagulasi. Jurnal Reaksi (Journal of Science and Technology). Vol.11 No. 1. Hlm 7-14

Gebbie, Petter (2005), “A Dummy's Guide to Coagulants". $68^{\text {th }}$ Annual Wate Industry Engineers and Operators, Conference Schweppes Centre, Bendigo.

Haslindah A., Zulkifi. (2012). Analisis Jumlah Koagulan (Tawas/A12(SO4)3) Yang Digunakan Dalam Proses Penjernihan Air
Pada Pdam Instalasi I Ratulangi Makassar. Jurnal ILTEK. Vol 7. No 13. Hlm 974-976

Kaswinarni, Fibria, 2007, Kajian Teknis Pengolahan Limbah Padat dan Cair Industri Tahu, Thesis Pasca Sarjana, Programstudi Ilmu Lingkungan, Universitas Diponegoro.

Kemen LH. (2014). Peraturan Menteri Lingkungan Hidup Nomer 5 Tahun 2014 Tentang Baku Mutu Air Limbah. Diakses dari

http://175.184.234.138/sipil/application/up loads/Baku_Mutu_Air_LimbahPermen_L H_No.5_Tahun_2015. 2017

Kristijarti, A Prima; Suharto, Ign; Marleana, 2013, Penentuan Jenis Koagulan dan Dosis Optimum Untuk Meningkatkan Efisiensi Sedimentassi dalam Instalasi Pengolahan Air Limbah Pabrik jamu X, Laporan Penelitian untuk Lembaga Penelitian da Pengabdian Masyarakat Universitas Katolik Parahyangan

Nirwana Sindya, 2016, Kinerja Pengolahan Limbah Cair Tahu Secara Kontinyu Dengan Media Filter Batu Fosfat, Skripsi, Fakultas Pertanian Universitas Lampung, Bandar lampung

Ningsih, R. 2011. Pengaruh Pembubuhan Tawas dalam Menurunkan TSS pada Air Limbah Sakit. Jurnal Kesehatan Masyarakat . 
Purwaningsih, 2007, Cara Pembuatan tahu dan Manfaat Kedelai. Ganesa Exact., Bekasi.

Pusteklim, 5 - 10 Februari 2007. Pelatihan Teknologi Tepat Guna Pengolahan Air limbah, Yogyakarta

Pratiwi Y. (2012). Uji Toksisitas Limbah Cair Laundry Sebelum Dan Sesudah Diolah Dengan Tawas Dan Karbon Aktif Terhadap Bioindikator (Cyprinuscarpio L). Prosiding, Seminar Nasional Aplikasi Sains \& Teknologi (SNAST) Periode III. Yogyakarta: IST Akprint.

Risdianto, Dian (2007), "Optimisasi Proses Koagulasi Flokulasi untuk Pengolahan Air Limbah Industri Jamu (Studi Kasus PT. Sido Muncul)", Program Pascasarjana Universitas Diponegoro, Semarang

Rizky, M Romadhon, 2016, Efektivitas Jenis Koagulan Dan Dosis Koagulan Terhadap Penurunan Nilai Kromium Limbah Peyamakan Kulit, Skripsi Sarjana, Fakultas Matematika Dan Ilmu Pengetahuan Alam Universitas Negeri Yogyakarta, Yogyakarta.

Russel, W B.;Saville, D A.; Schowalter, W R, 1989. Colloidal Dispersions. Cambridge, U.K.: Cambridge Univ. Press.

Ratnani, R.D. 2012. Kemampuan Kombinasi Eceng Gondok Dan Lumpur Aktif Untuk
Menurunkan Pencemaran Pada Limbah Cair Industri Tahu. Momentum, Vol. 8. No. $1: 1-5$.

Siregar, Sakti A, 2005, Instalasi Pengolahan Air Limbah, Kasinus, Yogyakarta, 111 halaman.

Soemirat, 2004. Kesehatan Lingkungan. Gadjah Mada University, Yogyakarta.

Suharto, 2011. Limbah Kimia dalam Pencemaran Udara dan Air, Andi, Yogyakarta, 518 halaman.

Supriyadi, 2014, Statistik Kesehatan, Salemba Medika, Jakarta, 164 halaman.

Supriyanto C. Dan Susanna T.S. (2011) Pengendalian Mutu Hasil Analisis Unsur $\mathrm{Pb}, \mathrm{Cd}$, Dan $\mathrm{Cr}$ Dalam Contoh Uji Air Limbah. Prosiding, Pertemuan dan Presentasi Ilmiah. Yogyakarta: BATAN.

Tarigan,M.S, Edward. 2003. Kandungan Total Zat Padat Tersuspensi (Total Suspended Solid) Perairan Raha, Jurnal Makara, Sains, Sulawesi Tenggara.

Yuliati, Suci, 2006, Proses Koagulasi-Flokulasi pada Pengolahan Tersier Limbah Cair PT Capsugel Indonesia, Skripsi Sarjana, Fakultas Teknologi Pertanian Institut Pertanian Bogor, Bogor. 